\title{
Design Of Portable Injection Waste Destruction Machine With Sterilization System
}

\author{
${ }^{* 1}$ Sandy Suryady, ${ }^{2}$ Eko Aprianto Nugroho, ${ }^{3}$ Abdul Muchlis \\ 1,2,3 Faculty of Industrial Engineering, Gunadarma University \\ ${ }^{*}$ Corresponding author: \\ Email: sandy22@staff.gunadarma.ac.id
}

\begin{abstract}
.
The Community Health Center (Puskesmas) does not yet have special facilities for treating medical waste such as hospitals. Hospital/Puskesmas waste and waste generated by hospital activities and other supporting activities. Make a machine that destroys waste injection equipment equipped with a knife made of SKD as a plastic syringe destroyer. Design of a syringe crushing machine in the form of needles and syringes, Analyze the von misses stress received by the frame structure of the syringe crusher, Analyze the displacement by the load received by the frame structure of the syringe crusher, Analyze the safety factor of the frame structure of the crusher syringe. Analyzing using solidworks 2016 software, the results obtained are the maximum value of von misses, displacement, and safety of factor from the lower frame of the syringe waste crusher machine. Von misses stress obtained in the analysis using Solidworks 2016 gets a value of 48.54 Mpa in software calculations, while in theoretical calculations it is $48.01 \mathrm{Mpa}$. The percentage of errors calculated by software and theory is $1 \%$. The displacement obtained in the analysis using Solidworks 2016 software is $0.34 \mathrm{~mm}$ in theoretical calculations of $0.35 \mathrm{~mm}$. The percentage of errors calculated by software and theory is $2 \%$. The safety factor obtained in the solidwork analysis gets a value of $4.7 \mathrm{ul}$ (upper limit), while the theoretical calculation is $5.2 \mathrm{ul}$ (upper limit) which means this frame is declared safe when the engine is operating.
\end{abstract}

Keywords:: Crusher, Frame, Solidworks

\section{INTRODUCTION}

Health services such as Community Health Centers (Puskesmas) do not yet have special facilities for treating medical waste such as hospitals. This causes the Puskesmas to dispose of medical waste such as syringes into public trash cans that can cause disease transmission. This makes the Puskesmas, which should be a role model for public health, have a bad image and are not properly accredited.Hospital/Puskesmas waste and waste are all generated by hospital activities and other supporting activities. When compared with the activities of other agencies, it can be said that the types of waste and hospital waste can be categorized as complex. In general, hospital/Puskesmas waste and waste are divided into two major groups, namely clinical and non-clinical waste, both solid and liquid.[1]This final project is to make a syringe and injection plastic waste destroyer equipped with a knife made of SKD as a syringe destroyer.

By utilizing a crusher during the needle crushing process, the crushing process is carried out separately in one machine, which is capable of crushing syringes and plastic syringes into millimeter-sized pieces. The result of this process is in the form of sterile plastic pieces measuring millimeters in size which can be used as raw material for plastic seeds which will become products such as buckets through a downcycling process. As well as pieces of sterile syringes measuring millimeters.[2]Previously, the Indonesian Institute of Sciences (LIPI) had developed a tool to destroy syringe waste by using an electrical arc that can crush metal syringes into powder. But not on plastic syringes or syringes and it becomes a problem to break it down.With the use of this tool, it is expected to be able to overcome the waste of injection equipment which reaches 30-50 syringes with a size of $1 \mathrm{ml}-50 \mathrm{ml}$ which are disposed of per day to be used up. The purpose of the shredder of medical waste injection equipment in the form of plastic and metal will be as a means of destroying the original form so that it becomes small pieces. This plastic and metal waste will be able to be recycled, melted again into materials for other products.[3] 


\section{LITERATURE REVIEW \\ Iron Steel ASTM A36}

Carbon steel is an alloy of $\mathrm{Fe}$ and $\mathrm{C}$ systems, usually mixed with other innate elements such as silicon $0.20 \%-0.70 \%$, Mn $0.50 \%-1.00 \%, \mathrm{P}<0.60 \%$ and $\mathrm{S}<0.06 \%$. According to Saito (2000), carbon steel according to its chemical composition is divided into the following:

- Low carbon steel with a carbon content of $0.05-0.3 \%$ (low carbon steel). It is malleable and easy to machine. Usually used for car bodies, buses and others.

- Medium carbon steel with a carbon content of 0.3-0.5\% (medium carbon steel). Its strength is higher than low carbon steel. It is difficult to bend, weld and cut. Its use is for building construction, materials for machine components, machetes, knives and others.

- High carbon steel with a carbon content of $0.5-1.5 \%$ (hight carbon steel). It is difficult to bend, weld and cut. Uses such as wire steel, pull and lift cables, files, chisels, and saws. Steels with a very low carbon content of less than $0.025 \%$ are called ferritic steels, and those containing $0.8 \%$ are called pearlitic steels.

Ferritic steel is almost similar to pure iron or contains only a small amount of carbon. Carbon gives strong and hard properties. Ferrite is weak but has ductile properties, only formed at low temperatures and is magnetic. Cementite is a compound between iron and carbon known as iron carbide (Fe3C), contains $6.67 \%$ carbon, is strong and hard and magnetic. Pearlite is a steel whose phase consists of a mixture of ferrite and cementite $(\alpha+\mathrm{Fe} 3 \mathrm{C})$, which is hard and magnetic.[8]

$$
\text { ASTM A36 }
$$

\begin{tabular}{lc|}
\hline Element & Content \\
Carbon, $\mathrm{C}$ & $0.25-0.290 \%$ \\
Copper, $\mathrm{Cu}$ & $0.20 \%$ \\
Iron, $\mathrm{Fe}$ & $98.0 \%$ \\
Manganese, $\mathrm{Mn}$ & $1.03 \%$ \\
Phosphorous, P & $0.040 \%$ \\
Silicon, $\mathrm{Si}$ & $0.280 \%$ \\
Sulfur, S & $0.050 \%$
\end{tabular}

\section{Mechanics of Strength in Materials}

One of the main problems of mechanics of materials is investigating internal resistance in the form of reactions or internal forces and deformation. Internal forces function to transmit external forces acting on a support and an object. In general, the internal force acting on an infinitely small area and a section, will consist of various magnitudes and directions. These internal forces are counterbalanced to the external and external forces exerted on the element and are usually inclined towards the plane of cut [9].

\section{RESEARCH METHOD}

\section{Flowchart of Performance Analysis of Injecting Waste Shredder}

The flow chart used for the manufacturing process of the syringe waste shredder is as follows.

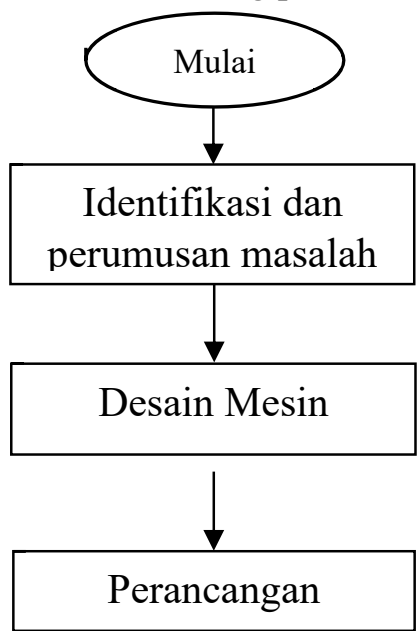




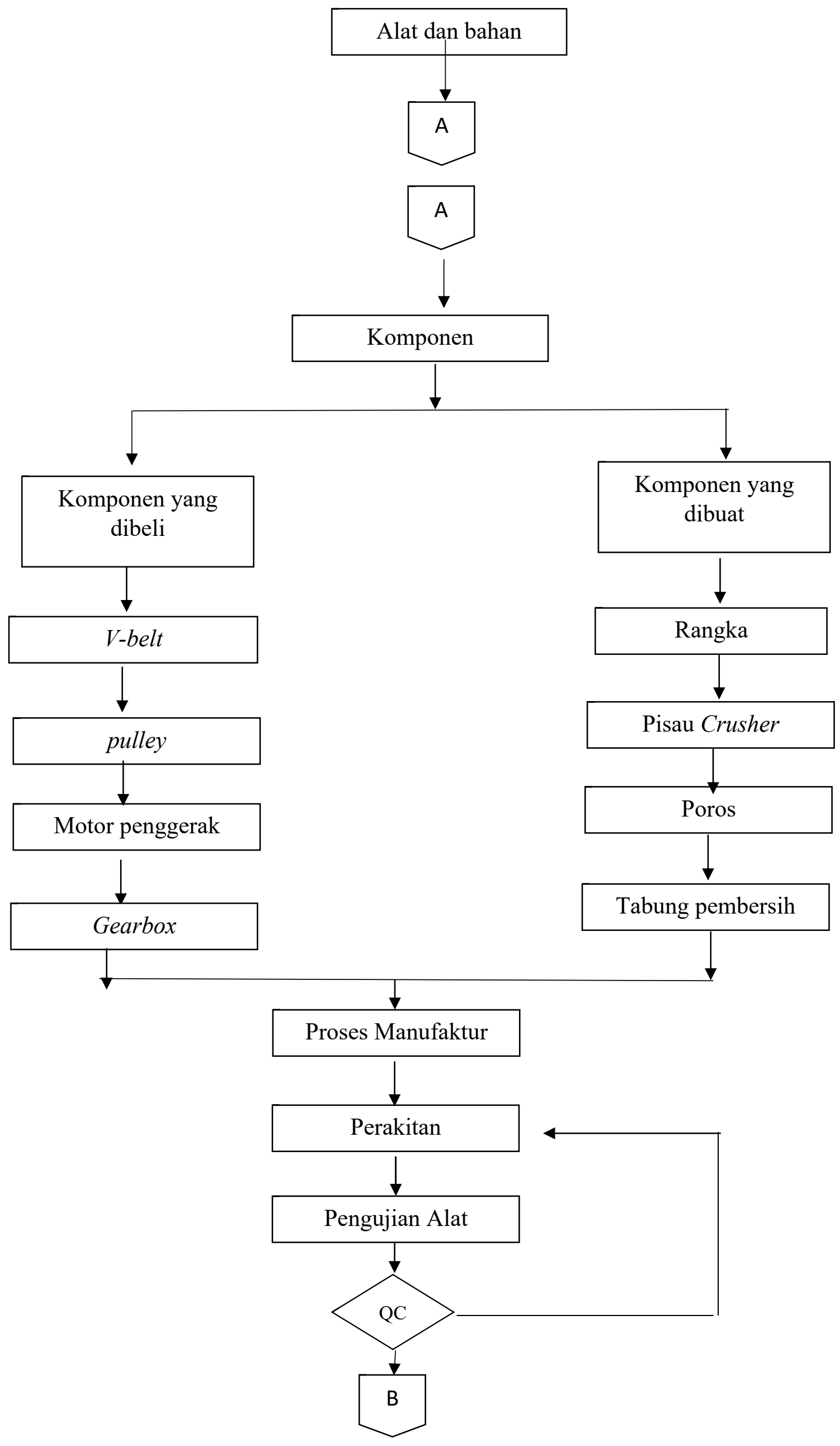




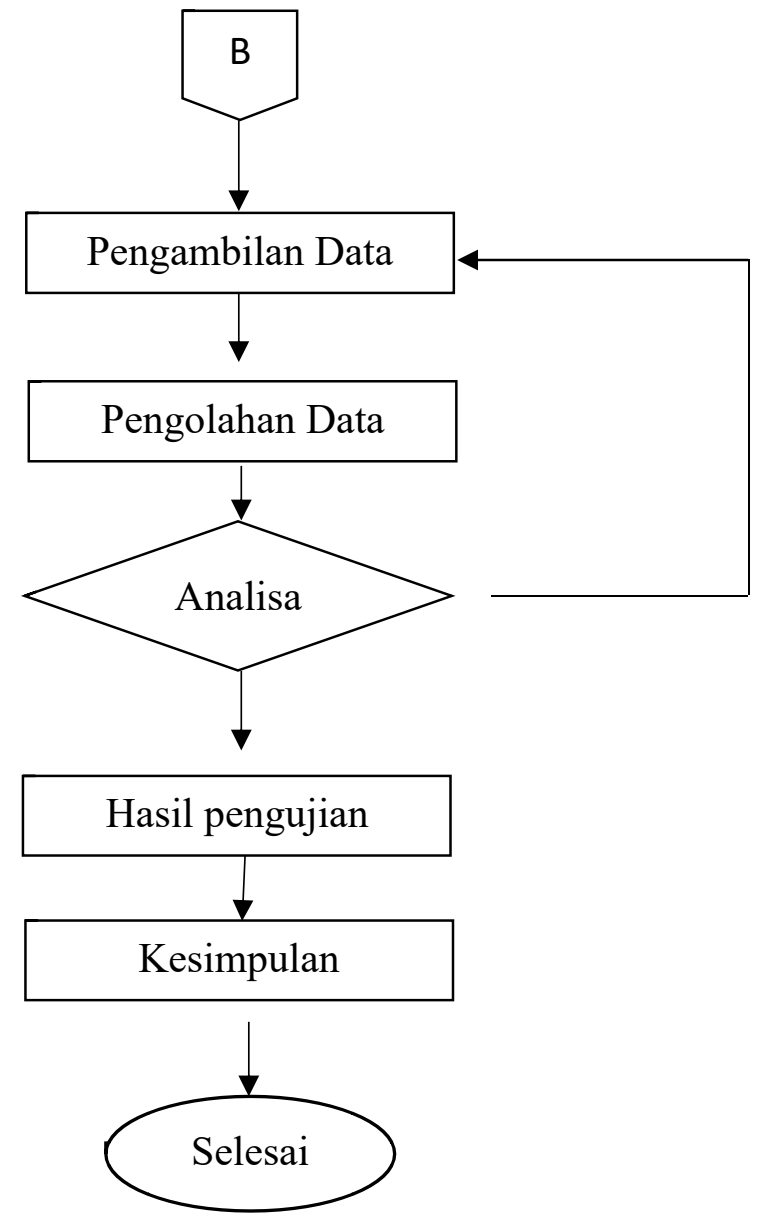

Flowchart of Static Load Analysis on Injecting Waste Shredder

Below is a flow chart used to analyze the framework of a syringe waste crusher machine.

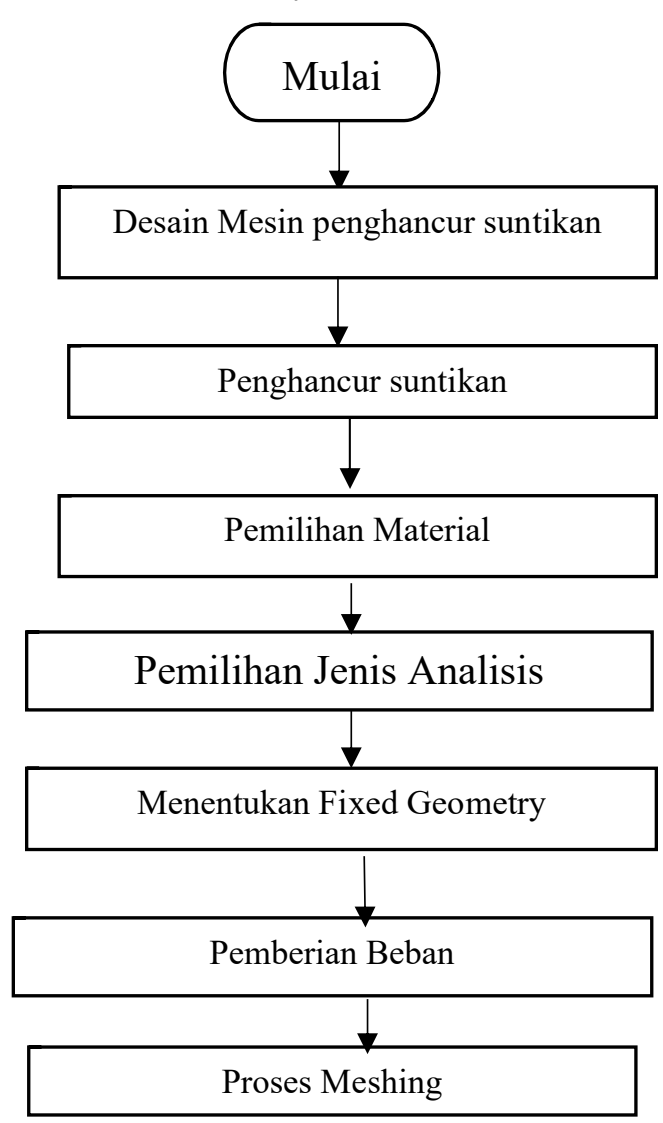




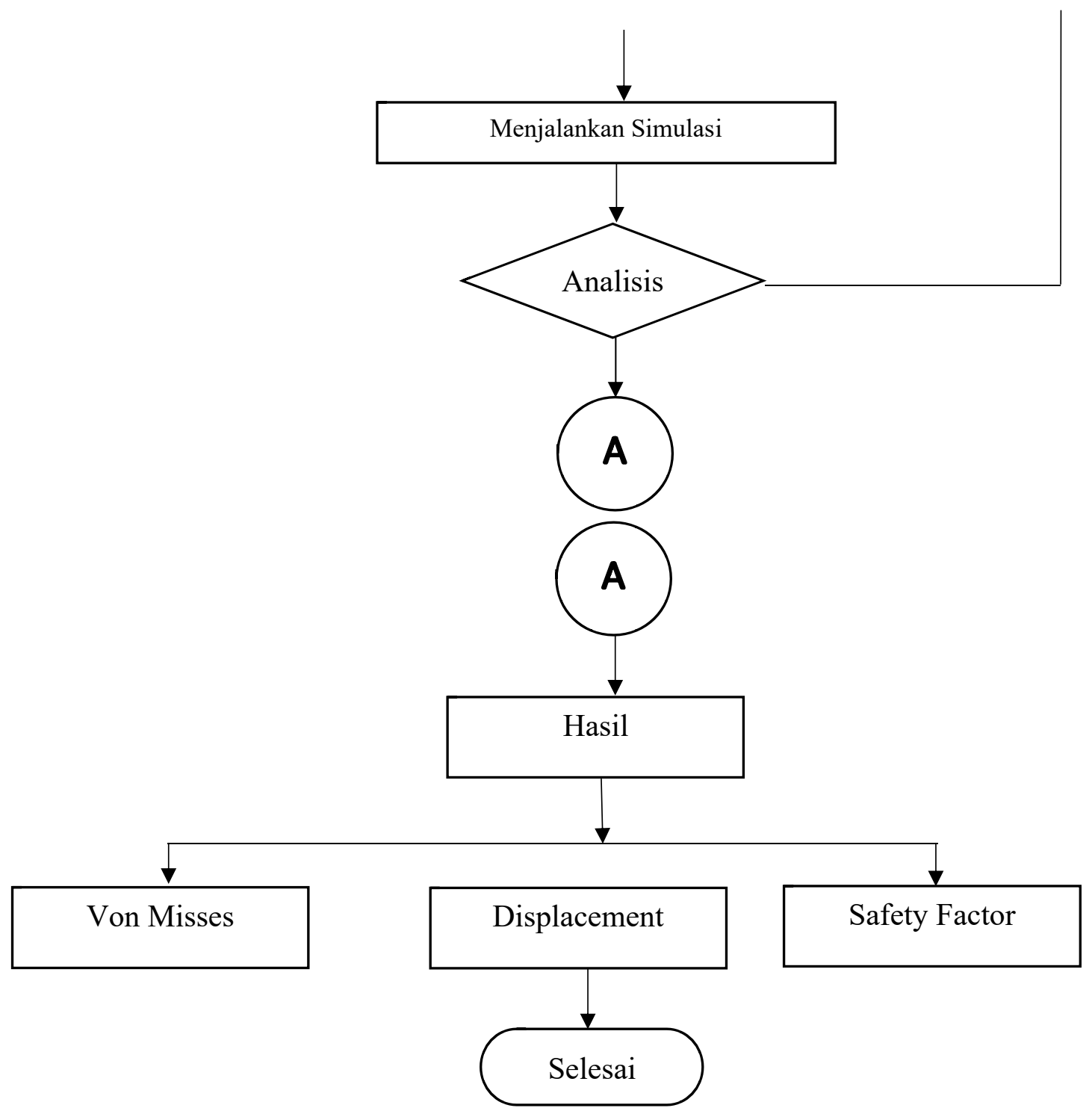

\section{RESULTS AND DISCUSSIONS}

\section{Stages of the Skeletal Analysis Process}

After the design of the Injectable Waste Shredder has been completed, the next step is to perform a simulation or analysis of the load received by the frame. Next, open the Solidworks software, then open the order file for the Injecting Waste Shredder Machine that was created earlier as shown below.

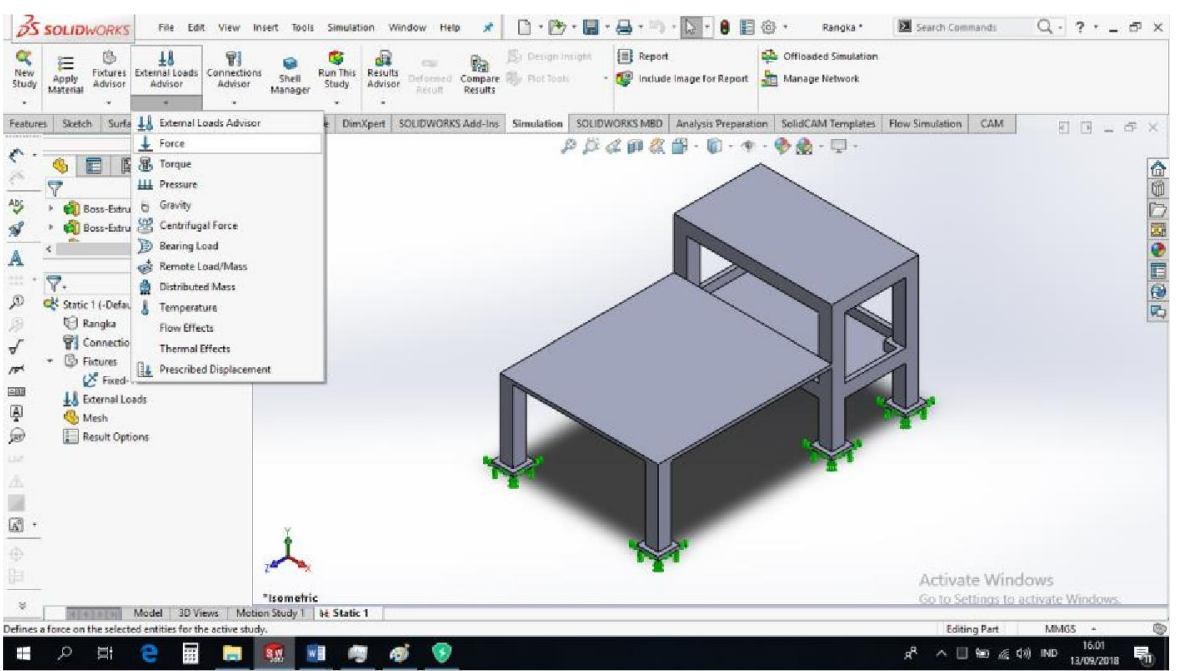




\section{Loading Stage}

The next stage is to provide a load on the frame to analyze the vulnerable points where damage occurs. In solidworks software there are several types of loading, namely: force, pressure, bearing load, moment load, gravity load. The step in giving the load is to click on the External Loads menu on the menu bar then select force then select the surface that is affected by the force and enter the amount of force applied then click

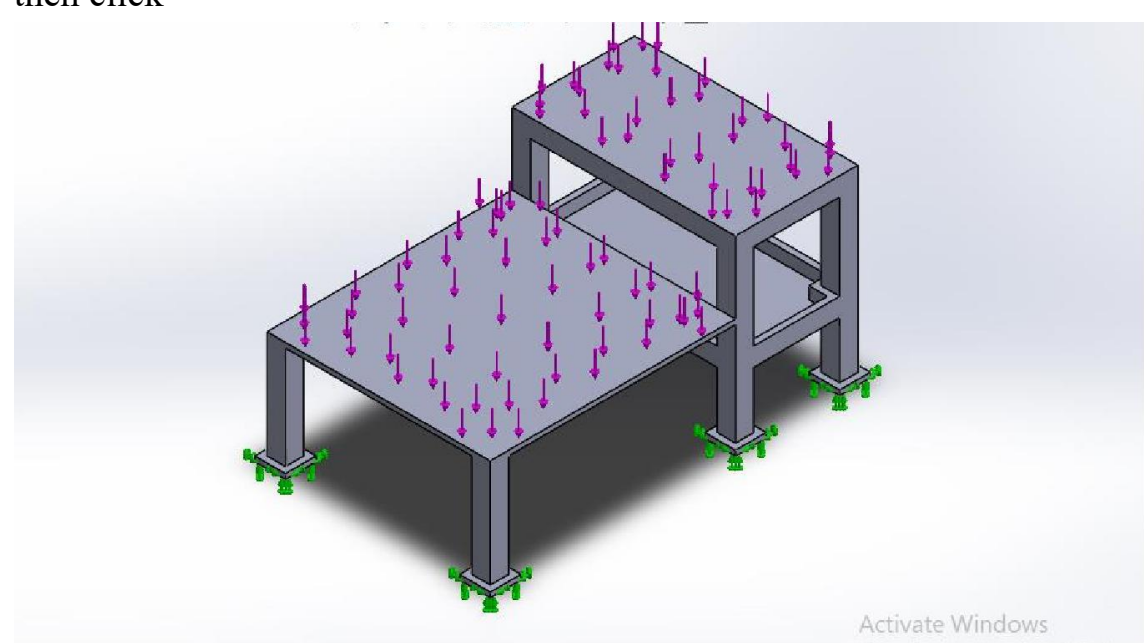

\section{Stage Mesh View}

This mesh process is a crystallization process from the frame model of the syringe waste shredder machine. By activating the mesh view, the nodes and elements contained in the frame of the syringe waste shredder will appear. The step in the mesh view is to click the Create Mesh menu on the menu bar then set the Mesh Density then click OK

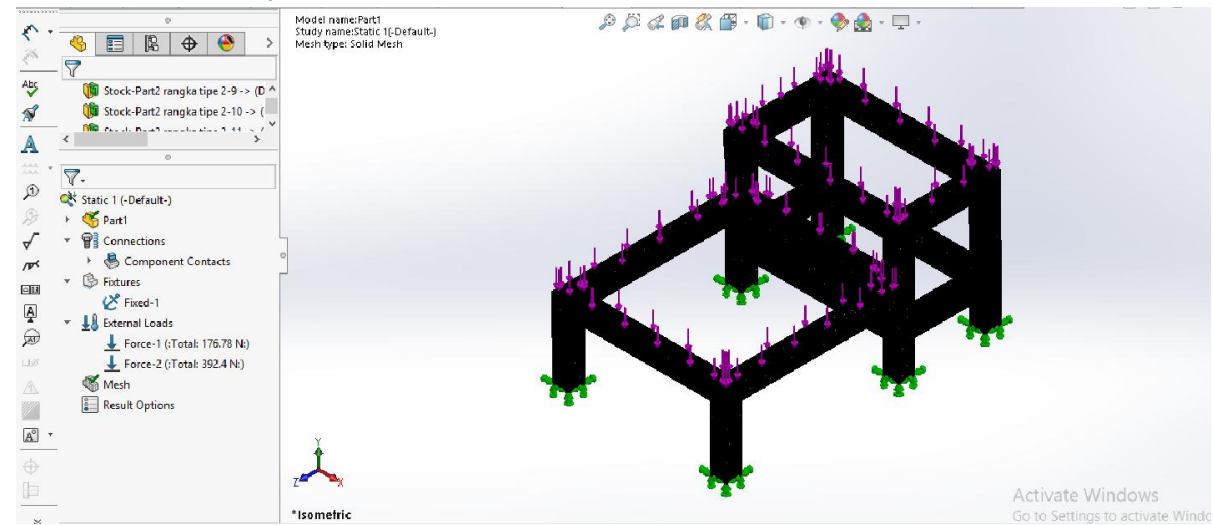

\section{Displacement}

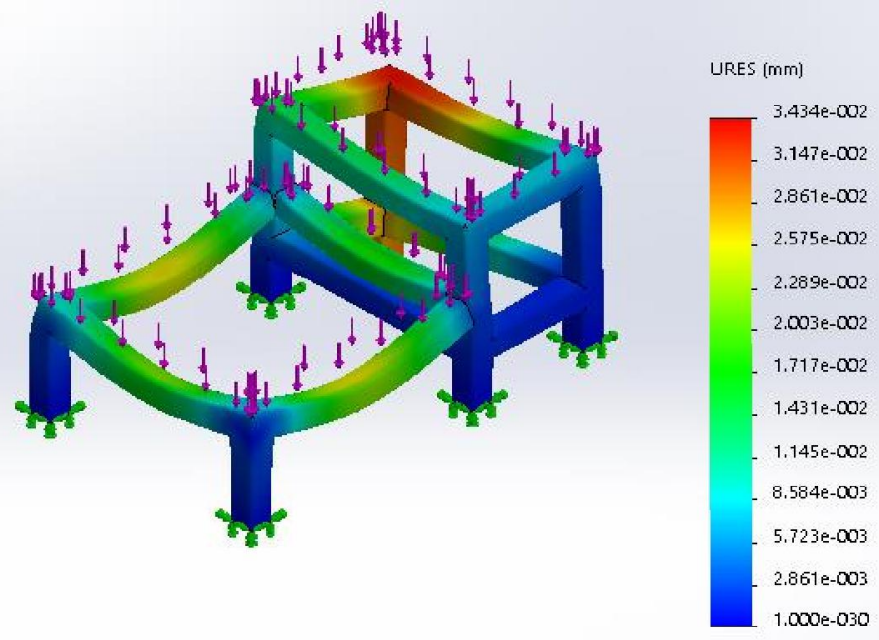




\section{Von Mises}
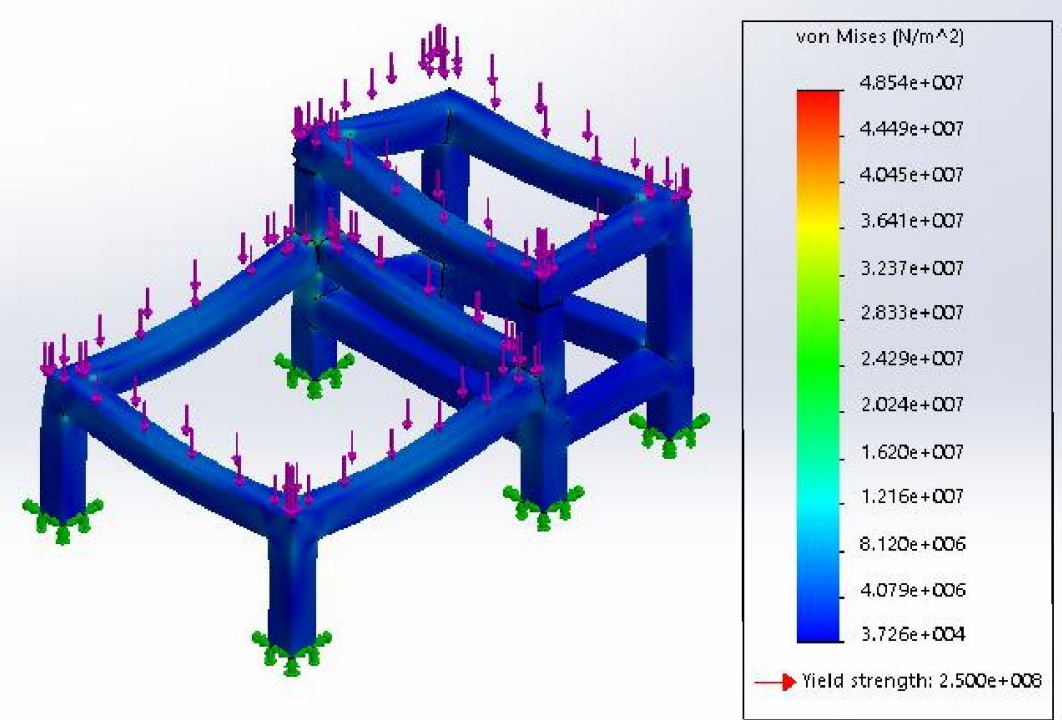

\section{Safety Factor}
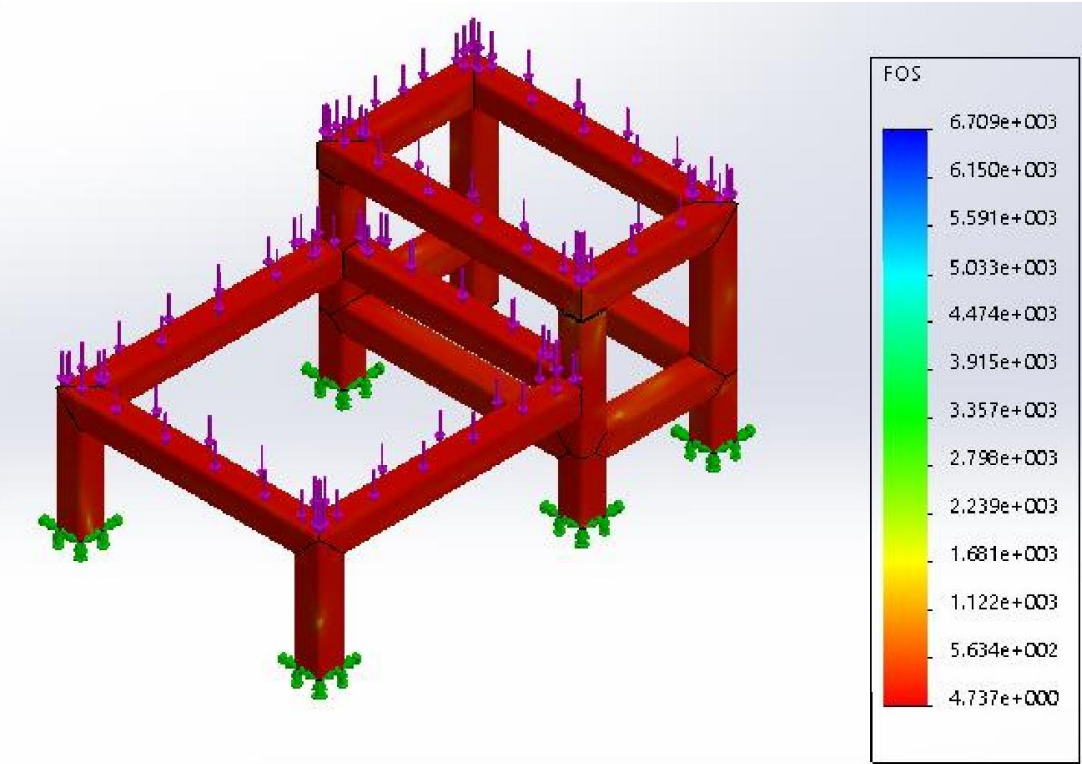

Comparison of Simulation Calculation Results with Calculations Based on Theoretical

\begin{tabular}{|c|c|c|c|c|c|c|}
\hline \multirow{2}{*}{ Nama } & \multicolumn{2}{|c|}{$\begin{array}{c}\text { Von misses stress } \\
\text { (Mpa) }\end{array}$} & \multicolumn{2}{c|}{$\begin{array}{c}\text { Displacement } \\
\text { (mm) }\end{array}$} & \multicolumn{2}{c|}{ Factor of Safety } \\
\cline { 2 - 7 } & Simulasi & Eksak & Simulasi & Eksak & Simulasi & Eksak \\
\hline $\begin{array}{c}\text { Rangka Mesin } \\
\text { Penghancur } \\
\text { Limbah Alat } \\
\text { Suntik }\end{array}$ & 48.54 & 48.01 & 0.34 & 0.35 & 4.7 & 5.2 \\
\hline $\begin{array}{c}\text { Galat Persentase } \\
\text { Perbedaan } \\
\text { Simulasi dan } \\
\text { Eksak. }\end{array}$ & \multicolumn{2}{|c|}{$1 \%$} & \multicolumn{2}{|c|}{$2 \%$} & \multicolumn{2}{|c|}{$9 \%$} \\
\hline
\end{tabular}

\section{CONSLUSION}

Based on the analysis and calculations that have been carried out starting from von misses, displacement and safety factors on the frame of the syringe crusher machine, several conclusions can be drawn: 
1. Design of a portable syringe waste crusher and sterilization system, using SS41, ASTM A36 steel and SKD materials, on the frame using a $40 \mathrm{~mm} \times 40 \mathrm{~mm} \times 1 \mathrm{~mm}$ hollow. SS41 is used for body material, ASTM A36 is used for hollow while crusher uses SKD material. The drive system uses an electric motor assisted by a gearbox as an intermediary to rotate the crusher and sterilization barrel.

2. Von misses stress obtained in the analysis using Solidworks 2014 software that the frame design of the syringe crusher machine using ASTM A36 Steel material gets a value of $48.54 \mathrm{Mpa}$ in software calculations, while in theoretical calculations it is $48.01 \mathrm{Mpa}$. The percentage of errors calculated by software and theory is $1 \%$.

3. Displacement obtained in the analysis using Solidworks 2014 software that the frame design of the waste shredder machine using ASTM A36 Steel material gets a value of $0.34 \mathrm{~mm}$ in software calculations, while in theoretical calculations it is $0.35 \mathrm{~mm}$. The percentage of errors calculated by software and theory is $2 \%$.

4. The safety factor obtained in the analysis using Solidworks 2014 software that the frame design of the syringe crusher machine using ASTM A36 steel material gets a Safety Factor value of 4.7 ul (Upper Limit) in software calculations, while in theoretical calculations it is $5.2 \mathrm{ul}$ (Upper Limit). which means this frame is declared safe when the engine is operating.

\section{SUGGESTIONS}

In the manufacture of the underframe of the syringe waste crusher machine there are shortcomings, therefore suggestions are needed to improve the tool:

1. Because this tool requires high precision, it is necessary to be careful about the type of support for the entire frame material, size and strong welded joints in order to properly machine components.

2. In conducting simulations on the 2016 Solidworks software, pay attention to the stages to perform the simulation, if any stage is missed, the results will be different from the theoretical results.

\section{REFERENCES}

[1] Asmadi. 2013. Pengelolaan Limbah Medis Rumah Sakit. Yogyakarta: Goysen Publishing.

[2] A. Purwanti. 2014. Evaluasi proses pengolahan limbah kulit udang untuk meningkatkan mutu kitosan yang dihasilkan. Jurnal Teknologi. vol. 7.

[3] Juli Soemirat Slamet. 2002. Kesehatan Lingkungan. Yogyakarta: Gajah Mada University.

[4] A.Pruss. 2005. Pengelolaan Aman Limbah Layanan Kesehatan. Jakarta : Penerbit Buku Kedokteran EGC.

[5] ILO dan WHO. 2005. Pedoman Bersama ILO/WHO tentang Pelayanan Kesehatan dan HIV/AIDS, Jakarta: Direktorat Pengawasan Kesehatan Kerja Direktorat Jenderal Pembinaan Pengawasan Ketenagakerjaan Departemen Tenaga Kerja dan Transmigrasi RI

[6] Tjandra Yoga Aditama dkk, 2006, Kesehatan dan Keselamatan Kerja, Jakarta: UI PRESS.

[7] Gere, James M, and Stephen P. Timoshenko. 1996. Mekanika Bahan. Jilid 1. Erlangga, Jakarta.

[8] Saito,S., Surdia T 2000. Pengetahuan Bahan Teknik, Pradnya Paramitha, Jakarta

[9] Zainun, Ahmad. 2006. Elemen Mesin 1 Edisi Kedua. Bandung : Refika Aditama.

[10] Hidayat, Nur dan Shanhaji, Ahmad. 2011. Solidworks Mastering 3D Mechanical Design. Bandung : Informatika.

[11] Luqman, Muhammad. 2014. Permodelan Chassis Dan Body Prototype Kendaraan Hybrid. Skripsi. Jurusan Teknik Mesin Universitas Gunadarma.

[12] POPOV, E.P, Zainul Astamar. 1994. Mekanika Teknik. Edisi Kedua. Erlangga, Jakarta.

[13] Sanyoto, Budi Luwar, dkk, 2018. Mesin penghancur sampah jarum suntik dan tabung suntik pelastik .Prosiding Seniati, Vol 4, No 2 Febuari 2018 Malang. Institut Teknologi Nasional Malang

[14] Etwin Fibrianie S, dkk. 2018. Rancang bangun mesin penggiling dan potong kerupuk ikan dengan menggunakan gearbox. Riset Teknologi Industri Vol. 12 No. Juni 2018 Politeknik Negeri Samarinda. Samarinda.

[15] Chandra Dewi Asmarhany. 2013. Pengelolaan Limbah Medis Padat Dirumah Sakit Umum Daerah Kelet Kabupaten Jepara. Kesmasindo, Vol, 7 No 3 2013. Universitas Negeri Semarang . Semarang. 